\title{
Immigrant Mothers' Knowledge of Medication Safety and Administration for Young Children
}

\author{
Wen-Tsung Huang ${ }^{1} \&$ Yu-Ching Yeh $^{2}$ \\ ${ }^{1}$ Division of Hemato-Oncology, Chi Mei Medical Center, Liouyin, Taiwan \\ ${ }^{2}$ Department of Early Childhood Education, National Chiayi University, Taiwan \\ Correspondence: Yu-Ching Yeh, Department of Early Childhood Education, National Chiayi University, \\ Wenlong Villiage, Mingshung County, Chiayi Hsian, 621, Taiwan. Tel: 88-65-226-9304. E-mail: \\ ycyeh@mail.ncyu.edu.tw
}

Received: March 12, 2015 Accepted: April 4, 2015 Online Published: May 16, 2015

doi:10.5539/ass.v11n13p276 URL: http://dx.doi.org/10.5539/ass.v11n13p276

\begin{abstract}
The goals of this paper are to compare immigrant (Southeast Asian and Chinese) and non-immigrant (Taiwanese) mothers' knowledge of medication safety and administration for children, and to reveal how the accessibility of medical resources could affect immigrant mothers' medication administration. The medication knowledge and communication ability of immigrants are suggested to be insufficient, which could be the main reason for medication errors. When medical resources can be accessed easily, immigrant mothers' medication errors may be reduced. A survey with stratified sampling was used. Data were gathered from 643 participants with young children in Taiwan. A researcher-designed questionnaire was used to solicit participants' responses concerning medication preservation and medication administration. Southeast Asian mothers need the help of doctors or family members; they frequently administer suppositories to febrile children, store children's medication in the fridge, and pay less attention to the expiry date. Chinese immigrant mothers tend to let children take Chinese medicine, give previously prescribed drugs to sick children, give other children's medication to sick children, and buy medicines at a pharmacy without a doctor's prescription. When the participants spend more than 31 minutes travelling to the nearest clinic, they are more likely to misuse medication, such as giving previously prescribed drugs to a sick child, and combining medication with Chinese medicine. The findings of this study suggest that the medication knowledge and administration habits of immigrant and non-immigrant mothers differ. The parents of young children take sick children to seek proper medical treatment when they are able to easily access medical resources.
\end{abstract}

Keywords: cultural issues, medication errors, medication management, public health education

\section{Introduction}

Medication errors have been reported to be the most common and preventable events that may harm children receiving treatment (Bates, 1996; Phillips et al., 2001). Medication safety includes the correct prescription and dispensing of medication. If we want to improve pediatric medication safety at home, one of the most important things needed is to enhance the medication knowledge of the parents or main caregivers (Hughes \& Edgerton, 2005). Culture and language barriers are thought to influence medication use and dosing accuracy among immigrants (Håkonsen \& Toverud, 2012; Lo, Sharif, \& Ozuah, 2006; Watt et al., 2012; Yin et al., 2010). Limited literacy proficiency and low social-economic status were the main reasons for medication errors in these populations (Chang, Chen, Chang, \& Smith, 2011; Håkonsen \& Toverud, 2012). It has been suggested that health professionals not only have to pay great attention to the communication of medical dosage information (Chang et al., 2011), but also need to put more effort into learning immigrants' beliefs about their illness and diminish the effects of unconscious bias (Suurmond, Uiters, de Bruijne, Stronks, \& Essink-Bot, 2011). Health care professionals are also expected to identify immigrants' medication management errors and provide information (Kao \& Lynn, 2009). Although these strategies could possibly improve the medication knowledge of immigrant parents, expecting health care professionals to learn multicultural beliefs or languages could go far beyond their capacity. There could be a variety of cultural beliefs and languages among diverse ethnicities, and furthermore, these strategies require long-term participation. If the immigrant families' medication administration patterns can be identified, we could adopt effective ways to reduce medication misuse. 
The aim of this study is to determine if accessibility to medical resources is a key factor in reducing immigrant mothers' medication errors. Accessibility to medical resources can be illustrated in two ways: the number of clinics per square $\mathrm{km}$ and the density of physicians per 1,000 population. In 2012, there were 21,437 clinics and hospitals in Taiwan (including 502 hospitals and 20,935 clinics), with at least one clinic for every 1.73 square km (Department of Health and Welfare, 2013). Taiwan has high population density and medical resources are easily accessed. The accessibility of medical resources can be illustrated by the density of physicians per 1,000 population: the average number of physicians per 1,000 population in Taiwan is 2.0 , similar to Japan (2.2) and Korea (2.0), and slightly lower than the USA (2.5), UK (2.8), and the OECD (Organisation for Economic Co-operation and Development [OECD]) average (3.2) (OECD Health Statistics, 2013) (Figure 1). Whether the accessibility of medical resources may improve the medication administration of immigrant parents needs further evaluation.

The purposes of this research study are three-fold: (i) to describe the medication knowledge and medication administration habits of immigrant mothers from Southeast Asia and the Peoples' Republic of China and those of nonimmigrant mothers; (ii) to compare medication knowledge and administration between immigrant and nonimmigrant mothers; and (iii) to examine the effects of nationality and accessibility of medical resources on medication administration. Identifying these factors can assist health professionals to highlight the goals of immigrant-based public health plans and to propose intervention strategies for medication administration.

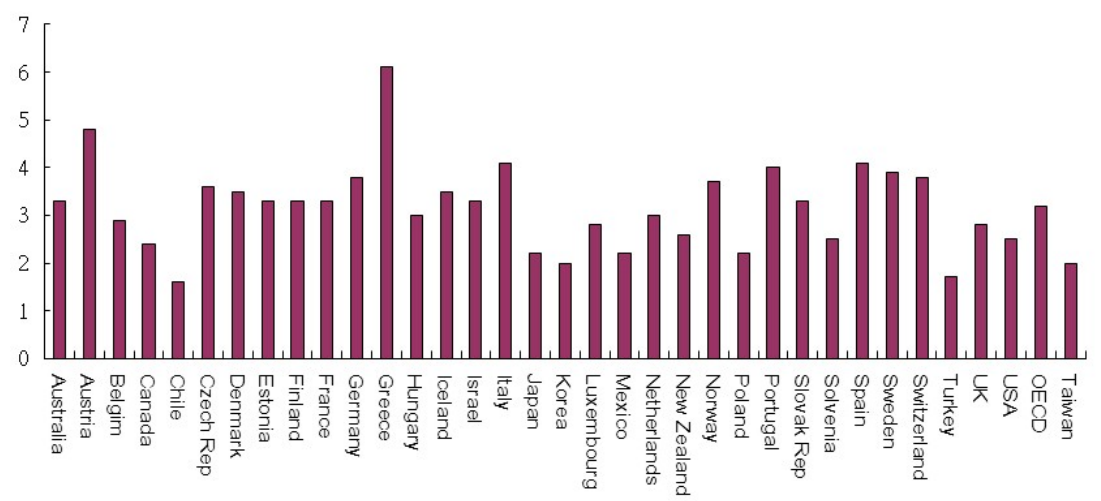

Figure 1. Physician density per 1000 population (OECD Health Statistics 2013)

\section{National Health Insurance in Taiwan}

National health services in Taiwan are inexpensive, and this facilitates the use of medical resources by immigrant families. Most people can easily access medical resources in Taiwan, even immigrants or socially disadvantaged families. The National Health Insurance program in Taiwan is a compulsory health insurance system, and benefits are provided during the insured term for illness, injury, or pregnancy. The central government, the group insurance applicant (for example, the employer), and the insured are required to jointly shoulder the insurance costs after promulgated revenues have been deducted. The premium payable by the insured is calculated according to the insured's net pay and [[the premium rate of the insured???]]. The insured and that person's dependents pay 30 percent of the premium, with the other 70 percent is paid by the group insurance applicants, or the group insurance applicants pay 60 percent of the premium, and the remaining 10 percent is subsidized by the central government. The patients pay a registration fee of approximately NT $\$ 150$ (equal to US\$5) and a copayment of NT\$50-NT\$360 for clinics and medical centers (equal to US\$1.7-US\$12). For children under 3 years and low-income families, the central government pays the copayment. The national health payment is affordable for most people (National Health Administration, 2014).

\section{Immigrants from Transnational Marriages}

Increased immigration has become a social trend in most OECD countries. The USA had the highest immigration rate (1,062 thousands) in 2011. The number of immigrants in countries such as Norway, the Russian Federation, Mexico, and the Netherlands increased more than 100\% from 2005 to 2011 (OECD 2013). Increases in immigration also mean increases in a country's expenditures for medical resources. In particular, immigration and emigration are common among EU countries; pharmacy services in the EU may not provide adequate assurance of medication safety for immigrants and thus, extensive minimum pharmacy practice standards for immigrant populations are needed (Väänänen, Lyles, \& Airaksinen, 2008). In Taiwan, immigration has increased 
due to transnational marriages (immigrant women married to Taiwanese men). There are 498,368 married immigrants in Taiwan (about 2.1\% of the total population) (National Immigration Agency 2015). Two-thirds of them are from the People's Republic of China (PRC), and the remainder is from Southeast Asian countries. The number of children from transnational marriage families who attend primary and junior high school was 211,445 in 2015 (Ministry of Education, 2015), approximately 10.3\% of students. Although the immigrant mothers have limited medication literacy, they are the main caregivers of their children. Young children particularly rely on their mothers for medication administration. How their immigrant background and bicultural experiences influence their medication knowledge and administration needs further study.

\section{Methods}

A questionnaire survey was developed using the available literature on medication errors, and in-depth interviews with immigrant mothers in Taiwan were conducted by the researchers. Twenty-six items were used to measure immigrant and non-immigrant mothers' medication safety knowledge (13 items), medication administration practices ( 8 items), and cultural aspects of medication (5 items). Medication safety knowledge reflects how parents store medication, and their perceptions concerning medication and folk remedies. Medication administration is defined as how parents administer medication to sick children, and questions regarding the keeping of unused medication, mixing medication with Chinese medicine, etc., were included. Accessibility of medical resources in this study was indicated by travel time to the nearest clinic, and included four categories: less than 10 minutes, 11-20 minutes, 21-30 minutes, and more than 31 minutes.

The National Immigration Agency in Taiwan initially approved the study and the questionnaire. Informed consent letters were sent to the participants with the questionnaires. In order to assist the immigrants understand the content, the consent letter was translated into Vietnamese and Chinese simplified characters. Additional permission was granted by the nursery schools to allow admittance and to send the questionnaires to specific subjects (i.e. immigrant mothers). The participants mailed back the anonymous questionnaires with the stamped envelopes prepared by the researchers. Their names and personal details were confidential.

A self-administered questionnaire, based on the results of the interviews, was sent to the mothers of 643 young children in four cities in the south of Taiwan. The participants had at least one preschool child aged 3-6. According to government statistics (2010), there were 21,607 immigrants from Southeast Asian countries in these four cities. The total number of immigrants (including Southeast Asian and PRC) was 34,304. The appropriate sampling size was determined according to the percentages of immigrants in each city, with an equivalent number of Taiwanese parents (Table 1). Multistage sampling was used: three areas in each city were randomly selected at the first stage, and 2-3 private and public nursery schools per area (total 33) were randomly selected at the second stage. The Taiwanese participants were randomly sampled from the same classes as the bi-ethnic children. The researchers contacted the directors to request their support and agreement to send the questionnaire to the young children's mothers. Participants were asked to self-administer the questionnaire, which took about 8-10 minutes to complete. The participants then sent back the questionnaires in the postage-stamped envelopes. The questionnaire was translated into Vietnamese and simplified Chinese for immigrant mothers to read without difficulty. Questionnaires were sent to 765 parents; the final response rate was $84 \%$, excluding unfinished and invalid questionnaires. The participants included 209 Southeast Asian immigrant mothers, 201 PRC immigrants, and 233 Taiwanese. There was a 95\% confidence level for the total sample, with a $\pm 6 \%$ confidence interval (CI).

Table 1. Number of immigrants from the four cities and the sample size

\begin{tabular}{|c|c|c|c|c|c|}
\hline \multirow[b]{2}{*}{ City } & \multicolumn{2}{|l|}{ Local populations } & & \multicolumn{2}{|c|}{ Sample size $(n=643)$} \\
\hline & $\begin{array}{l}\text { Immigrants from S.E. } \\
\text { Asia }(N)\end{array}$ & $\begin{array}{l}\text { Immigrants from } P R \\
\text { China }(\mathrm{N})\end{array}$ & $\begin{array}{l}\text { Immigrants } \\
\text { Population } \\
\mathrm{N}(\%)\end{array}$ & $\begin{array}{l}\text { Immigrant } \\
\text { participants } \\
\mathrm{N}(\%)\end{array}$ & $\begin{array}{l}\text { Taiwanese } \\
\text { Participants } \\
\mathrm{N}(\%)\end{array}$ \\
\hline $\begin{array}{l}\text { Yuling } \\
\text { County }\end{array}$ & 6458 & 8311 & $14769(23.7 \%)$ & $99(24.1 \%)$ & $59(25.3 \%)$ \\
\hline $\begin{array}{l}\text { Chiayi } \\
\text { County }\end{array}$ & 5081 & 7056 & $12137(19.5 \%)$ & $88(21.5 \%)$ & $53(22.7 \%)$ \\
\hline Chiayi City & 1300 & 3241 & $4541(7.3 \%)$ & $45(11.0 \%)$ & $20(8.6 \%)$ \\
\hline Tainan City & 10060 & 20734 & $30794(49.5 \%)$ & $178(43.4 \%)$ & $101(43.4 \%)$ \\
\hline Total & 21607 & 12697 & $62241(100 \%)$ & 410 & 233 \\
\hline
\end{tabular}

Note: Data from National Immigration Agency (2013). 
A researcher-designed questionnaire comprising 26 items was used to solicit parents' medication knowledge and administration practices. The questionnaire was designed using a four-point Likert scale, ranging from "always" (4 points) to "never" (1 point). Demographic data included parent's (or main caregiver's) nationality and education level. Content validity was established through expert review. The questionnaire was developed and reviewed by five experts, including a pediatric pharmacist, professors in public health and nursing, and immigrant and non-immigrant mothers. The instrument was pretested with five immigrant mothers and five non-immigrant mothers who were not part of the study. Based on the pretesting, only minor grammatical changes were made. Cronbach's alpha was applied to test the internal consistency of the questionnaire regarding parents' medication safety knowledge and administration practices. The Cronbach's alpha was $0.771, \mathrm{KMO}=$ 0.67 .

All statistical tests were performed using SPSS 12.0 for Windows. Descriptive statistics (frequency, percentage, mean, SD, and range) were used to describe the distributions of demographic data, and parents' medication preservation, medication administration, and medication supervision. Chi-square tests and Scheffe post hoc tests were used to analyze differences among nationalities, education levels, and parents' perceptions of medication treatments. Two-way analyses of variance (ANOVA) were adopted to clarify the effects of nationality and education on medication preservation, medication administration, and medication supervision. A $p$-value of $<0.05$ was used to indicate significance.

\section{Results and Discussions}

\subsection{Sample Characteristics}

A total of 643 returned questionnaires were included in this study. Among the participants, $32.5 \%(n=209)$ were Southeast Asian immigrants, $31.3 \%(n=201)$ were PRC immigrants, and $36.2 \%(n=233)$ were Taiwanese. The main educational levels of the participants were senior high school $(36.1 \%, n=232)$ and junior high school $(30 \%, n=193)$. The educational level of the Southeast Asian immigrant mothers was lower than average, mainly junior high $(41.1 \%, n=86)$ and primary school $(27.2 \%, n=57)$. The percentage of immigrant mothers from PR China who had junior and senior high school diplomas was $78.6 \%(n=158)$. The percentage of Taiwanese mothers who had senior high school diplomas and university/college degrees was $80.7 \%(n=188)$.

\subsection{Parents' Medication Safety Knowledge}

Table 2. Medication safety knowledge and administration by nationality $(\mathrm{n}=643)$

\begin{tabular}{|c|c|c|c|c|c|c|c|c|}
\hline \multirow{3}{*}{ item } & \multicolumn{8}{|c|}{ Nationalities } \\
\hline & \multicolumn{2}{|c|}{$\begin{array}{l}\text { Southeast } \\
\text { Asia } \\
(\mathrm{n}=209)\end{array}$} & \multicolumn{2}{|c|}{$\begin{array}{l}\text { PR China }(n= \\
\text { 201) }\end{array}$} & $\begin{array}{l}\text { Taiwan } \\
\text { 233) }\end{array}$ & $(\mathrm{n}=$ & \multirow[t]{2}{*}{$\begin{array}{l}F \text {-Value } \\
\text { (Sig.) }\end{array}$} & \multirow[t]{2}{*}{$\begin{array}{l}\text { Scheffe } \\
\text { Post Hoc }\end{array}$} \\
\hline & Mean & SD & Mean & SD & Mean & SD & & \\
\hline Notice the expiry date of medication & 3.69 & 0.79 & 3.67 & 0.73 & 3.87 & 0.44 & $6.99 * *$ & $\begin{array}{l}\mathrm{TW}>\mathrm{SE}, \\
\mathrm{TW}>\mathrm{CN}\end{array}$ \\
\hline Keep unfinished prescription drugs & 2.08 & 1.15 & 2.30 & 1.02 & 2.12 & 1.01 & 2.52 & \\
\hline Go to clinics or hospitals & 3.56 & 0.86 & 3.75 & 0.62 & 3.83 & 0.50 & $8.89 * * *$ & $\begin{array}{l}\mathrm{CN}>\mathrm{SE}, \\
\mathrm{TW}>\mathrm{SE}\end{array}$ \\
\hline Buy medicines at pharmacy & 1.58 & 0.96 & 1.63 & 0.89 & 1.38 & 0.67 & $5.46^{* *}$ & $\mathrm{CN}>\mathrm{TW}$ \\
\hline $\begin{array}{l}\text { Give previously prescribed drugs to } \\
\text { sick child }\end{array}$ & 1.56 & 0.88 & 1.79 & 0.92 & 1.60 & 0.76 & $3.95^{*}$ & $\mathrm{CN}>\mathrm{SE}$ \\
\hline $\begin{array}{l}\text { Give other children's medication to } \\
\text { sick child }\end{array}$ & 1.24 & 0.66 & 1.48 & 0.90 & 1.23 & 0.58 & $8.11^{* * *}$ & $\begin{array}{l}\mathrm{CN}>\mathrm{SE}, \\
\mathrm{CN}>\mathrm{TW}\end{array}$ \\
\hline Notice the drug names on drug pack & 3.28 & 1.07 & 3.17 & 1.03 & 3.44 & 0.83 & $4.15^{*}$ & $\mathrm{TW}>\mathrm{CN}$ \\
\hline $\begin{array}{l}\text { Understand medication administration } \\
\text { description }\end{array}$ & 3.43 & 0.95 & 3.52 & 0.89 & 3.63 & 0.73 & 2.81 & \\
\hline $\begin{array}{l}\text { Do not understand side effects of } \\
\text { medication }\end{array}$ & 2.31 & 1.11 & 2.44 & 1.16 & 2.36 & 1.04 & 0.57 & \\
\hline Request to grind pills into powder & 3.16 & 1.15 & 2.88 & 1.18 & 2.77 & 1.23 & $5.50 * *$ & $\mathrm{SE}>\mathrm{TW}$ \\
\hline $\begin{array}{l}\text { Need assistance from doctors or family } \\
\text { members to explain how to } \\
\text { administrate mediation }\end{array}$ & 2.47 & 1.14 & 1.95 & 1.14 & 1.49 & 0.73 & $49.17 * * *$ & $\begin{array}{l}\mathrm{SE}>\mathrm{CN}> \\
\mathrm{TW}\end{array}$ \\
\hline
\end{tabular}




\begin{tabular}{|c|c|c|c|c|c|c|c|c|}
\hline \multirow{3}{*}{ item } & \multicolumn{8}{|c|}{ Nationalities } \\
\hline & \multicolumn{2}{|c|}{$\begin{array}{l}\text { Southeast } \\
\text { Asia } \\
(\mathrm{n}=209)\end{array}$} & \multicolumn{2}{|c|}{$\begin{array}{l}\text { PR China }(n= \\
\text { 201) }\end{array}$} & $\begin{array}{l}\text { Taiwan } \\
\text { 233) }\end{array}$ & $(\mathrm{n}=$ & \multirow[t]{2}{*}{$\begin{array}{l}F \text {-Value } \\
\text { (Sig.) }\end{array}$} & \multirow[t]{2}{*}{$\begin{array}{l}\text { Scheffe } \\
\text { Post Hoc }\end{array}$} \\
\hline & Mean & SD & Mean & SD & Mean & SD & & \\
\hline $\begin{array}{l}\text { Insist children need to take all the } \\
\text { prescribed medication }\end{array}$ & 2.88 & 1.17 & 3.01 & 1.02 & 2.95 & 1.00 & 0.70 & \\
\hline $\begin{array}{l}\text { Decide whether children need to stop } \\
\text { medication or not }\end{array}$ & 2.54 & 1.18 & 2.72 & 1.05 & 2.61 & 1.00 & 1.28 & \\
\hline Throw away unfinished prescriptions & 2.86 & 1.18 & 2.81 & 1.09 & 3.07 & 1.04 & $3.49^{*}$ & $\mathrm{TW}>\mathrm{CN}$ \\
\hline Store unfinished prescriptions in fridge & 2.44 & 1.20 & 2.30 & 1.21 & 2.09 & 1.14 & $4.81 * *$ & $\mathrm{SE}>\mathrm{TW}$ \\
\hline Let children take Chinese medicine & 2.03 & 1.09 & 2.02 & 1.02 & 2.06 & 1.03 & 0.08 & \\
\hline Take sick children for acupuncture & 1.26 & 0.74 & 1.30 & 0.72 & 1.15 & 0.53 & 2.63 & \\
\hline $\begin{array}{l}\text { Let sick children take medication and } \\
\text { Chinese medicine at the same time }\end{array}$ & 1.26 & 0.74 & 1.59 & 1.02 & 1.39 & 0.78 & $7.33^{* *}$ & $\mathrm{CN}>\mathrm{SE}$ \\
\hline $\begin{array}{l}\text { Worry that children taking too much } \\
\text { medication is not good for their health }\end{array}$ & 3.23 & 0.96 & 3.13 & 1.04 & 3.28 & 0.96 & 1.14 & \\
\hline $\begin{array}{l}\text { Worry that children's medication } \\
\text { contains an antibiotic }\end{array}$ & 2.77 & 1.16 & 3.18 & 1.01 & 3.33 & 0.95 & $15.57 * * *$ & $\begin{array}{l}\mathrm{CN}>\mathrm{SE} \\
\mathrm{TW}>\mathrm{SE}\end{array}$ \\
\hline $\begin{array}{l}\text { Administer suppository to febrile } \\
\text { children }\end{array}$ & 3.17 & 0.91 & 2.96 & 0.94 & 2.85 & 0.89 & $6.58 * *$ & $\mathrm{SE}>\mathrm{TW}$ \\
\hline frightening the evil spirit & 1.78 & 1.00 & 2.18 & 0.99 & 2.11 & 0.96 & $9.38^{* * *}$ & $\mathrm{CN}>\mathrm{SE}$ \\
\hline $\begin{array}{l}\text { Worship by lighting incense sticks in } \\
\text { the temples }\end{array}$ & 1.71 & 1.03 & 1.81 & 0.97 & 1.73 & 0.93 & 0.56 & \\
\hline Hide scissors underneath pillow & 1.23 & 0.71 & 1.34 & 0.76 & 1.06 & 0.37 & $10.76^{* *}$ & $\mathrm{SE}>\mathrm{TW}$ \\
\hline Sprinkle urine around child's bed & 1.14 & 0.59 & 1.21 & 0.62 & 1.05 & 0.36 & $4.88^{* *}$ & $\mathrm{CN}>\mathrm{TW}$ \\
\hline Apply Chi Gung for sick children & 1.19 & 0.56 & 1.25 & 0.69 & 1.11 & 0.51 & $3.26^{*}$ & $\mathrm{CN}>\mathrm{TW}$ \\
\hline
\end{tabular}

Note: ${ }^{*} \mathrm{p}<.05,{ }^{* *} \mathrm{p}<.01,{ }^{* * *} \mathrm{p}<.001 ;$ TW: Taiwan, CN: PR China, SE: Southeast Asia

Immigrant and non-immigrant parents demonstrated a similar uniformity of emphasizing the importance of medication safety knowledge and administration. Most parents were concerned about the following medication issues (Table 2): (1) the expiry date of medication $(M=3.74)$; (2) taking sick children to clinics or hospitals $(M$ $=3.71)$; (3) understanding the description of medication administration on drug packaging $(M=3.53)$; and (4) noticing the drug names on the packaging $(M=3.30)$. Intrusive treatment such as acupuncture was adopted less often by parents $(M=1.24)$. Other infrequent types of medication knowledge include: (1) giving other children's medication to a sick child ( $M=1.32)$; (2) letting sick children take medication and Chinese medicine at the same time $(M=1.41)$; and (3) buying medicines at a pharmacy without a doctor's prescription $(M=1.53)$. The above concerns could be due to the fact that the medication is for young children under 6 years, which causes parents to pay particular attention to the drug names, expiry date, and descriptions on the drug packaging. The parents also expressed a common perception of negative side effects from taking medication. They worry that taking too much medication is not good for their children's health $(M=3.21)$. The main reason is that the parents believe the medication contains antibiotics $(M=3.09)$.

\subsection{Impact of Immigrant Background on Medication}

Scheffe post hoc tests were used to test differences among nationalities. Southeast Asian mothers expressed the need for assistance from doctors or family members to explain how to administer medication $(M=2.47, F=$ $49.17^{* * *}$ ). They also tended to administer suppositories to febrile children more often than Taiwanese parents $\left(M=3.17, F=6.58^{* *}\right)$. Southeast Asian parents were accustomed to storing children's medication in the fridge $\left(M=2.44, F=4.81^{* *}\right)$, but they paid less attention to the expiry date of medication than did Taiwanese parents $(F=6.99 * *)$. Chinese immigrants tended to let children take Chinese medicine and medication at the same time, unlike Southeast Asian mothers $(M=1.59, F=7.33)$. The Chinese immigrants tended to give previously prescribed drugs to sick children $\left(F=3.95^{*}\right)$, and they would give other children's medication to sick children $\left(F=8.11^{* * *}\right)$. They also preferred to buy medicines at a pharmacy without a doctor's prescription $\left(F=5.457^{* *}\right)$ (Table 3). 
Table 3. Duration of travel to nearest clinic by nationality

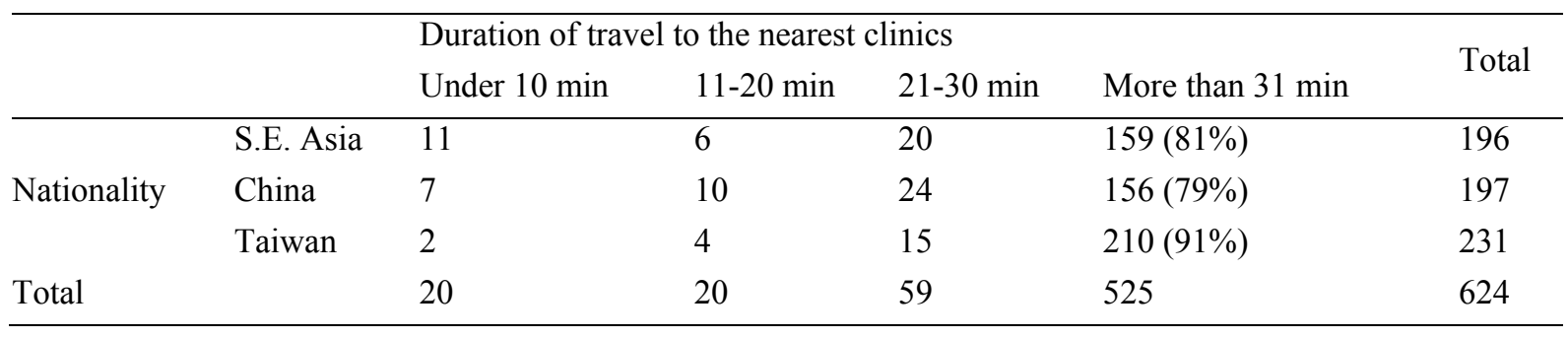

\subsection{Cultural Aspects of Medication and Alternative Therapy}

Table 4. Two-way ANOVA of medication behaviors by nationality and duration of travel to the nearest clinic

\begin{tabular}{|c|c|c|c|c|c|}
\hline & $\begin{array}{l}\text { Type III sum of } \\
\text { squares }\end{array}$ & $d f$ & $\begin{array}{l}\text { Mean } \\
\text { Square }\end{array}$ & $F$ & Sig. \\
\hline \multicolumn{6}{|c|}{ Notice the expiry date of medication } \\
\hline Nationality & 4.482 & 2 & 2.241 & 2.355 & .096 \\
\hline Duration & 21.560 & 3 & 7.187 & 7.553 & $.000 * * *$ \\
\hline Nationality with duration & 1.026 & 6 & .171 & .180 & .982 \\
\hline \multicolumn{6}{|c|}{ Keep unfinished prescription drugs } \\
\hline Nationality & 3.850 & 2 & 1.925 & 5.156 & $.006^{* *}$ \\
\hline Duration & 34.265 & 3 & 11.422 & 30.591 & $.000 * * *$ \\
\hline Nationality with duration & 7.899 & 6 & 1.316 & 3.526 & $.002 * *$ \\
\hline \multicolumn{6}{|l|}{ Go to clinics or hospitals } \\
\hline Nationality & 5.690 & 2 & 2.845 & 3.779 & $.023 *$ \\
\hline Duration & 18.176 & 3 & 6.059 & 8.049 & $.000 * * *$ \\
\hline Nationality with duration & 5.679 & 6 & .946 & 1.257 & .275 \\
\hline \multicolumn{6}{|c|}{$\begin{array}{l}\text { Buy medicines at pharmacy without a doctor's } \\
\text { prescription }\end{array}$} \\
\hline Nationality & 2.597 & 2 & 1.299 & 1.556 & .212 \\
\hline Duration & 60.114 & 3 & 20.038 & 24.010 & $.000 * * *$ \\
\hline Nationality with duration & 8.183 & 6 & 1.364 & 1.634 & .135 \\
\hline \multicolumn{6}{|c|}{ Give previously prescribed drugs to sick child } \\
\hline Nationality & 3.408 & 2 & 1.704 & 2.746 & .065 \\
\hline Duration & 54.410 & 3 & 18.137 & 29.228 & $.000 * * *$ \\
\hline Nationality with duration & 3.403 & 6 & .567 & .914 & .484 \\
\hline \multicolumn{6}{|c|}{ Give other children's medication to sick child } \\
\hline Nationality & 1.161 & 2 & .581 & .488 & .614 \\
\hline Duration & 7.107 & 3 & 2.369 & 1.990 & .114 \\
\hline Nationality with duration & 10.333 & 6 & 1.722 & 1.447 & .194 \\
\hline \multicolumn{6}{|c|}{ Notice the drug names on drug pack } \\
\hline Nationality & .712 & 2 & .356 & .128 & .880 \\
\hline Duration & 27.070 & 3 & 9.023 & 3.237 & $.022 *$ \\
\hline Nationality with duration & 32.483 & 6 & 5.414 & 1.942 & .072 \\
\hline \multicolumn{6}{|c|}{ Request to grind pills into power } \\
\hline Nationality & 1.034 & 2 & .517 & .462 & .630 \\
\hline Duration & 1.061 & 3 & .354 & .316 & .814 \\
\hline Nationality with duration & 9.379 & 6 & 1.563 & 1.396 & .214 \\
\hline \multicolumn{6}{|c|}{ Throw away unfinished prescriptions } \\
\hline Nationality & 7.826 & 2 & 3.913 & 9.518 & $.000 * * *$ \\
\hline Duration & 5.969 & 3 & 1.990 & 4.839 & $.002 * *$ \\
\hline
\end{tabular}




\begin{tabular}{llllll}
\hline & $\begin{array}{l}\text { Type III sum of } \\
\text { squares }\end{array}$ & $d f$ & $\begin{array}{l}\text { Mean } \\
\text { Square }\end{array}$ & $F$ & Sig. \\
\hline Nationality with duration & 8.652 & 6 & 1.442 & 3.508 & $.002^{* *}$ \\
Store unfinished prescriptions in fridge & & & & & \\
Nationality & 7.698 & 2 & 3.849 & 5.346 & $.005^{* *}$ \\
Duration & 3.987 & 3 & 1.329 & 1.846 & .138 \\
Nationality with duration & 6.469 & 6 & 1.078 & 1.498 & .176 \\
Let children take Chinese medicine & & & & & \\
Nationality & 1.419 & 2 & .709 & .775 & .461 \\
Duration & 38.558 & 3 & 12.853 & 14.044 & $.000^{* * *}$ \\
Nationality with duration & 6.626 & 6 & 1.104 & 1.207 & .301 \\
Take sick children for acupuncture & & & & & \\
Nationality & 2.099 & 2 & 1.050 & 1.046 & .352 \\
Duration & 39.417 & 3 & 13.139 & 13.089 & $.000^{* * *}$ \\
Nationality with duration & 15.145 & 6 & 2.524 & 2.514 & $.021^{*}$ \\
Let sick children take medication & & & & & \\
medicine at the same time & and & & & & \\
Nationality & 1.219 & 2 & .610 & .776 & .461 \\
Duration & 8.185 & 3 & 2.728 & 3.473 & $.016^{*}$ \\
Nationality with duration & 16.372 & 6 & 2.729 & 3.474 & $.002^{* *}$ \\
\hline
\end{tabular}

$* \mathrm{p}<.05, * * \mathrm{p}<.01, * * \mathrm{p}<.001$

Cultural aspects of medication and alternative therapy were also discussed. According to interviews with Southeast Asian immigrant mothers (Yeh \& Huang, 2012), hiding scissors underneath the pillow and sprinkling urine around children's beds are folk or religious remedies to treat sick children in Southeast Asia. However, we did not find that Southeast Asian mothers adopted folk remedies for febrile children $(M<1.5)$. Many Chinese and Taiwanese believed that Chinese medicine is mild and had fewer side effects for children. Few participants, including immigrant and non-immigrant mothers, used Chinese medicine $(M=2.04)$, "qigong" (an internal system generally considered to be the genesis of Chinese martial arts) $(M=1.18)$, "frightening the evil spirit" $(M$ $=2.03)$, or "worshiping by lighting incense sticks in the temples" $(M=1.74)$ (Table 4). Although folk treatments are commonly observed in daily life, the parents of young children intended to take children to clinics or doctors instead of relying on folk remedies. We interpreted this to mean that when the accessibility to medical resources is convenient for parents, they will use the proper medication.

\subsection{Impact of Accessibility of Medical Resources on Medication Administration Practices}

Most parents needed more than 31 minutes to reach the nearest clinic $(n=525,84 \%)$. Compared with Taiwanese parents, $81 \%$ of the Southeast Asian immigrant mothers and $79 \%$ of the Chinese immigrant mothers spent more than 31 minutes traveling to the nearest clinic (Table 5). Immigrant mothers do not have more difficulties in obtaining medical resources than Taiwanese mothers.

Medication use behaviors were compared (using two-way ANOVAs) using nationality and duration of travel to the nearest clinic as the independent variables (Table 6). The duration of travel to the nearest clinic had a significant effect on medication administration. The accessibility of medical resources influenced parents' noticing the expiry date of medication $\left(F=7.533^{* * *}\right)$, buying medication at a pharmacy without a doctor's prescription $\left(F=24.010^{* * *}\right)$, going to clinics or hospitals $\left(F=8.049^{* * *}\right)$, giving previously prescribed drugs to a sick child $\left(F=29.228^{* * *}\right)$, throwing away unfinished prescriptions $\left(F=4.839^{* * *}\right)$, letting children take Chinese medicine $\left(F=14.044^{* * *}\right)$, taking sick children for acupuncture $\left(F=13.089^{* * *}\right)$, and letting children take medication and Chinese medicine at the same time $\left(F=3.473^{* * *}\right)$. 
Table 5. Duration of travel to nearest clinic and medication behaviors $(n=643)$

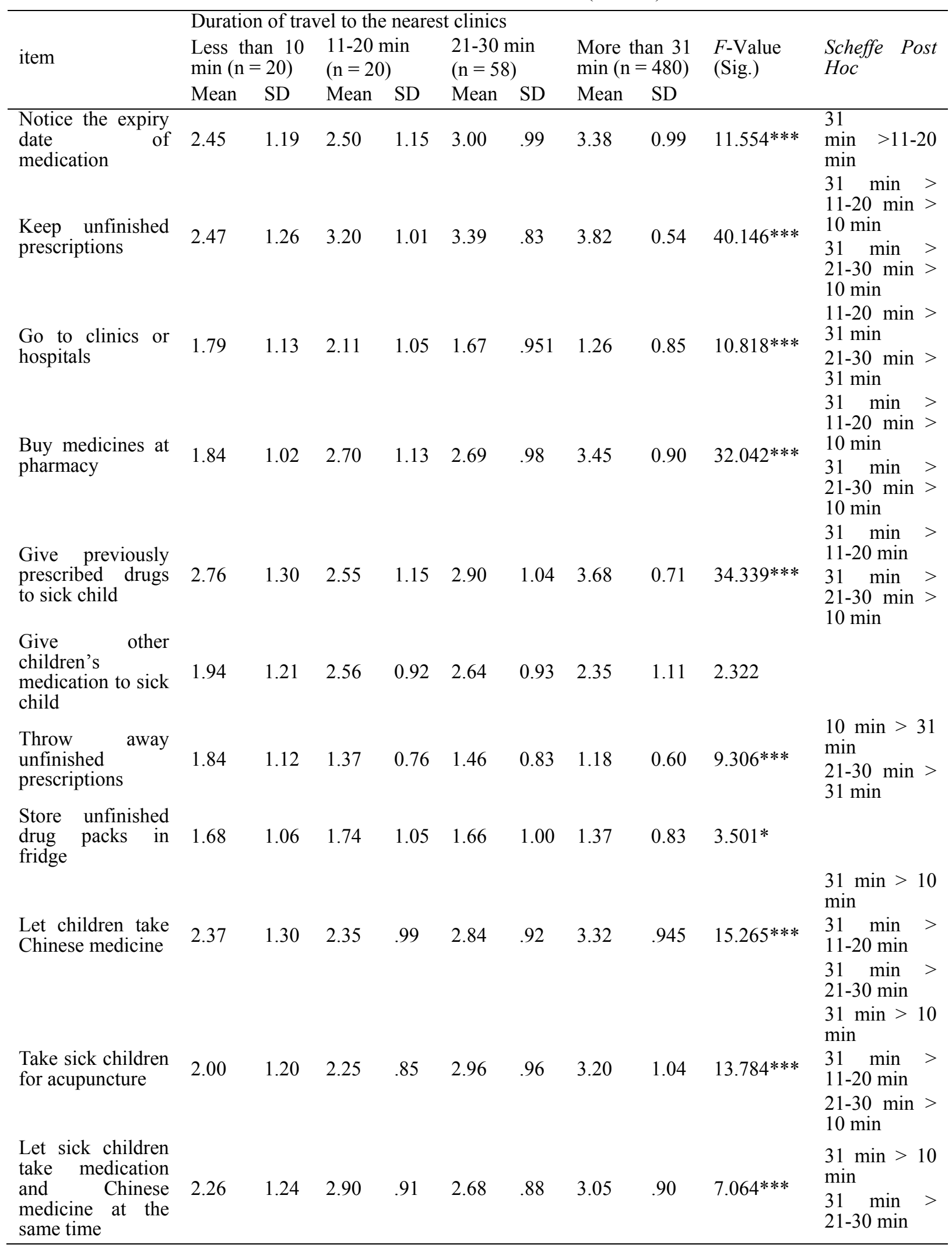

${ }^{*} \mathrm{p}<.05, * * * p<.001 ;$ TW: Taiwan, CN: PR China, SE: Southeast Asia 
Table 6. Two-way ANOVA of medication behaviors by nationality and duration of travel to the nearest clinic

\begin{tabular}{|c|c|c|c|c|c|}
\hline & $\begin{array}{l}\text { Type III sum of } \\
\text { squares }\end{array}$ & $d f$ & $\begin{array}{l}\text { Mean } \\
\text { Square }\end{array}$ & $F$ & Sig. \\
\hline \multicolumn{6}{|c|}{ Notice the expiry date of medication } \\
\hline Nationality & 4.482 & 2 & 2.241 & 2.355 & .096 \\
\hline Duration & 21.560 & 3 & 7.187 & 7.553 & $.000^{* * *}$ \\
\hline Nationality with duration & 1.026 & 6 & .171 & .180 & .982 \\
\hline \multicolumn{6}{|c|}{ Keep unfinished prescription drugs } \\
\hline Nationality & 3.850 & 2 & 1.925 & 5.156 & $.006^{* *}$ \\
\hline Duration & 34.265 & 3 & 11.422 & 30.591 & $.000^{* * *}$ \\
\hline Nationality with duration & 7.899 & 6 & 1.316 & 3.526 & $.002 * *$ \\
\hline \multicolumn{6}{|l|}{ Go to clinics or hospitals } \\
\hline Nationality & 5.690 & 2 & 2.845 & 3.779 & $.023 *$ \\
\hline Duration & 18.176 & 3 & 6.059 & 8.049 & $.000^{* * *}$ \\
\hline Nationality with duration & 5.679 & 6 & .946 & 1.257 & .275 \\
\hline \multicolumn{6}{|c|}{$\begin{array}{l}\text { Buy medicines at pharmacy without a doctor's } \\
\text { prescription }\end{array}$} \\
\hline Nationality & 2.597 & 2 & 1.299 & 1.556 & .212 \\
\hline Duration & 60.114 & 3 & 20.038 & 24.010 & $.000 * * *$ \\
\hline Nationality with duration & 8.183 & 6 & 1.364 & 1.634 & .135 \\
\hline \multicolumn{6}{|c|}{ Give previously prescribed drugs to sick child } \\
\hline Nationality & 3.408 & 2 & 1.704 & 2.746 & .065 \\
\hline Duration & 54.410 & 3 & 18.137 & 29.228 & $.000^{* * *}$ \\
\hline Nationality with duration & 3.403 & 6 & .567 & .914 & .484 \\
\hline \multicolumn{6}{|c|}{ Give other children's medication to sick child } \\
\hline Nationality & 1.161 & 2 & .581 & .488 & .614 \\
\hline Duration & 7.107 & 3 & 2.369 & 1.990 & .114 \\
\hline Nationality with duration & 10.333 & 6 & 1.722 & 1.447 & .194 \\
\hline \multicolumn{6}{|c|}{ Notice the drug names on drug pack } \\
\hline Nationality & .712 & 2 & .356 & .128 & .880 \\
\hline Duration & 27.070 & 3 & 9.023 & 3.237 & $.022 *$ \\
\hline Nationality with duration & 32.483 & 6 & 5.414 & 1.942 & .072 \\
\hline \multicolumn{6}{|c|}{ Request to grind pills into power } \\
\hline Nationality & 1.034 & 2 & .517 & .462 & .630 \\
\hline Duration & 1.061 & 3 & .354 & .316 & .814 \\
\hline Nationality with duration & 9.379 & 6 & 1.563 & 1.396 & .214 \\
\hline \multicolumn{6}{|c|}{ Throw away unfinished prescriptions } \\
\hline Nationality & 7.826 & 2 & 3.913 & 9.518 & $.000 * * *$ \\
\hline Duration & 5.969 & 3 & 1.990 & 4.839 & $.002 * *$ \\
\hline Nationality with duration & 8.652 & 6 & 1.442 & 3.508 & $.002 * *$ \\
\hline \multicolumn{6}{|c|}{ Store unfinished prescriptions in fridge } \\
\hline Nationality & 7.698 & 2 & 3.849 & 5.346 & $.005^{* *}$ \\
\hline Duration & 3.987 & 3 & 1.329 & 1.846 & .138 \\
\hline Nationality with duration & 6.469 & 6 & 1.078 & 1.498 & .176 \\
\hline \multicolumn{6}{|c|}{ Let children take Chinese medicine } \\
\hline Nationality & 1.419 & 2 & .709 & .775 & .461 \\
\hline Duration & 38.558 & 3 & 12.853 & 14.044 & $.000^{* * *}$ \\
\hline Nationality with duration & 6.626 & 6 & 1.104 & 1.207 & .301 \\
\hline \multicolumn{6}{|c|}{ Take sick children for acupuncture } \\
\hline Nationality & 2.099 & 2 & 1.050 & 1.046 & .352 \\
\hline Duration & 39.417 & 3 & 13.139 & 13.089 & $.000^{* * *}$ \\
\hline Nationality with duration & 15.145 & 6 & 2.524 & 2.514 & $.021 *$ \\
\hline
\end{tabular}




\begin{tabular}{lllllll}
\hline & $\begin{array}{l}\text { Type III sum of } \\
\text { squares }\end{array}$ & $d f \begin{array}{l}\text { Mean } \\
\text { Square }\end{array}$ & $F$ & Sig. \\
\hline $\begin{array}{l}\text { Let sick children take medication and Chinese medicine } \\
\text { at the same time }\end{array}$ & & & & & & \\
Nationality & 1.219 & 2 & .610 & .776 & .461 \\
Duration & 8.185 & 3 & 2.728 & 3.473 & $.016^{*}$ \\
Nationality with duration & 16.372 & & 6 & 2.729 & 3.474 & $.002^{* *}$ \\
\hline
\end{tabular}

${ }^{*} p<.05, * * p<.01, * * * p<.001$

The participants reported that when they had to spend more than 31 minutes to reach the nearest clinic, they tended to be more cautious about the expiry date of medication $\left(F=11.554^{* * *}\right)$ and keeping unfinished prescriptions $\left(F=40.146^{* * *}\right)$. However, they could possibly misuse medication more often, such as giving previously prescribed drugs to a sick child $\left(F=34.339^{* * *}\right)$ (Table 7). These parents were also more likely to adopt alternative treatments, such as Chinese medicine $\left(F=15.265^{* * *}\right)$, acupuncture $\left(F=13.784^{* * *}\right)$, and mixing medication and Chinese medicine at the same time $\left(F=7.064^{* * *}\right)$ (Table 5). The parents may adopt alternative treatments for their sick children when their medical resources are limited. However, whether parents gave other children's medication to sick children was not found to be significantly related to the accessibility of medical resources. This could be because most parents were aware of the possible misuse and negative effects of cross-child medications.

Table 7. Duration of travel to nearest clinic and medication behaviors $(n=643)$

\begin{tabular}{|c|c|c|c|c|c|c|c|c|c|c|}
\hline \multirow{3}{*}{ item } & \multicolumn{8}{|c|}{ Duration of travel to the nearest clinics } & \multirow[t]{3}{*}{$\begin{array}{l}F \text {-Value } \\
\text { (Sig.) }\end{array}$} & \multirow[t]{3}{*}{$\begin{array}{l}\text { Scheffe } \\
\text { Post Hoc }\end{array}$} \\
\hline & \multicolumn{2}{|c|}{$\begin{array}{l}\text { Less than } 10 \\
\min (n=20)\end{array}$} & \multicolumn{2}{|c|}{$\begin{array}{l}11-20 \min (n \\
=20)\end{array}$} & \multicolumn{2}{|c|}{$\begin{array}{l}21-30 \min (\mathrm{n} \\
=58)\end{array}$} & \multicolumn{2}{|c|}{$\begin{array}{l}\text { More than } 31 \\
\min (n=480)\end{array}$} & & \\
\hline & Mean & SD & Mean & SD & Mean & SD & Mean & SD & & \\
\hline $\begin{array}{l}\text { Notice the expiry date } \\
\text { of medication }\end{array}$ & 2.45 & 1.19 & 2.50 & 1.15 & 3.00 & .99 & 3.38 & 0.99 & $11.554 * * *$ & \\
\hline $\begin{array}{l}\text { Keep unfinished } \\
\text { prescriptions }\end{array}$ & 2.47 & 1.26 & 3.20 & 1.01 & 3.39 & .83 & 3.82 & 0.54 & $40.146^{* * *}$ & \\
\hline $\begin{array}{l}\text { Go to clinics or } \\
\text { hospitals }\end{array}$ & 1.79 & 1.13 & 2.11 & 1.05 & 1.67 & .951 & 1.26 & 0.85 & $10.818^{* * *}$ & \\
\hline $\begin{array}{l}\text { Buy medicines at } \\
\text { pharmacy }\end{array}$ & 1.84 & 1.02 & 2.70 & 1.13 & 2.69 & .98 & 3.45 & 0.90 & $32.042 * * *$ & \\
\hline $\begin{array}{lll}\text { Give } & \text { previously } \\
\text { prescribed } & \text { drugs } & \text { to } \\
\text { sick child } & & \end{array}$ & 2.76 & 1.30 & 2.55 & 1.15 & 2.90 & 1.04 & 3.68 & 0.71 & $34.339 * * *$ & \\
\hline $\begin{array}{l}\text { Give other children's } \\
\text { medication to sick } \\
\text { child }\end{array}$ & 1.94 & 1.21 & 2.56 & 0.92 & 2.64 & 0.93 & 2.35 & 1.11 & 2.322 & \\
\hline $\begin{array}{ll}\text { Throw } & \text { away } \\
\text { unfinished } & \\
\text { prescriptions } & \end{array}$ & 1.84 & 1.12 & 1.37 & 0.76 & 1.46 & 0.83 & 1.18 & 0.60 & $9.306 * * *$ & \\
\hline $\begin{array}{l}\text { Store unfinished drug } \\
\text { packs in fridge }\end{array}$ & 1.68 & 1.06 & 1.74 & 1.05 & 1.66 & 1.00 & 1.37 & 0.83 & $3.501^{*}$ & \\
\hline $\begin{array}{l}\text { Let children take } \\
\text { Chinese medicine }\end{array}$ & 2.37 & 1.30 & 2.35 & .99 & 2.84 & .92 & 3.32 & .945 & $15.265^{* * *}$ & \\
\hline $\begin{array}{l}\text { Take sick children for } \\
\text { acupuncture }\end{array}$ & 2.00 & 1.20 & 2.25 & .85 & 2.96 & .96 & 3.20 & 1.04 & $13.784 * * *$ & \\
\hline $\begin{array}{l}\text { Let sick children take } \\
\text { medication and } \\
\text { Chinese medicine at } \\
\text { the same time }\end{array}$ & 2.26 & 1.24 & 2.90 & .91 & 2.68 & .88 & 3.05 & .90 & $7.064 * * *$ & $\begin{array}{l}31 \min > \\
10 \min \\
31 \min > \\
21-30 \\
\text { min }\end{array}$ \\
\hline
\end{tabular}

${ }^{*} \mathrm{p}<.05, * * * \mathrm{p}<.001 ; \mathrm{TW}$ : Taiwan, CN: PR China, SE: Southeast Asia 
Immigrant mothers are the main caregivers and administer medications to their children. However, the limited literacy proficiency and limited knowledge of medications of immigrant mothers are perceived to be obstacles to appropriate medication administration (Yin et al., 2010; Väänänen et al., 2008; Chang et al., 2011; Wilson, Chen, Grumback, Wang, \& Fernandez, 2005; DeWalt, Drilling, Rosenthal, \& Pignone, 2007). Making medication information easier to read and understand, such as bilingual instructions on medication packaging, as well as using pictograms and less medical jargon, would be beneficial to enhancing medication knowledge (Chang et al., 2011; Yin et al., 2008). Even if we improve immigrants' access to standardized written information about medicines in their own language, not all of the problems related to medication safety will be solved (Väänänen et al., 2008). The effects of multilingual explanations need to be studied further. However, this study revealed that immigrant mothers tended to adopt particular medication administration habits, such as storing medication in the refrigerator, administering medication to other sick children, reducing the dosage or discontinuing medication, and mixing Chinese medicines with medication. They stored unfinished medications from previous visits to outpatient clinics for future use and even for other sick children. Health care professionals can assist immigrant mothers by clarifying possible medication errors and helping them change habits to minimize administration errors.

\section{Conclusions}

This study led to an important finding: if families can easily access medical resources, inappropriate medication administration, such as saving medication for future use, mixing medication with Chinese medicine, etc. could be reduced. Previous research has indicated that health literacy could predict medication comprehension (Marks, Schectman, Groninger, \& Plews-Ogan, 2010). If medication packages contained bilingual explanations, as well as pictograms and less medical jargon, reading and comprehension would be easier; thus, immigrants would know more about medications (Chang et al., 2011; Yin et al., 2008). However, providing bilingual explanations may be difficult in a multi-ethnic country because of various drug names and languages. This study concludes that appropriate medication administration correlates to accessibility of medical resources, rather than nationality. In other words, if health care professionals can improve the accessibility of medication, medication administration errors could be reduced among both immigrant and nonimmigrant mothers.

The study demonstrates two aspects of accessibility to medical resources that facilitate the reduction of medication misuse. In the case of Taiwan, the NHI expenditure is low and the density of clinics is high (at least one clinic every 1.73 square $\mathrm{km}$ ). However, the average number of physicians per 1,000 population is still lower than in most countries, including the USA, the UK, and most OECD countries. Medical conditions remain diversified in different countries. We suggest that health care professionals can redefine the "accessibility of their medical resources" and determine the best solutions for medication misuse in immigrant families.

The parents of young children take sick children to clinics instead of relying on traditional folk remedies or buying medicine from pharmacies without prescriptions. However, medication administration misuse, such as mixing Chinese medicine with medication, and administering previously prescribed medication to a sick child, is frequently found among immigrant families. Although immigrant parents have difficulties in reading instructions and drug names on drug packaging, previous research cannot inform us as to whether bilingual supplements would reduce medication administration misuse. This study indicates differences in medication knowledge and administration habits between immigrant and non-immigrant mothers. Nevertheless, the effects of nationality will be reduced when the accessibility of medical resources becomes convenient. The parents of young children would be more likely to take sick children for proper medical treatment and not keep previously prescribed drugs for future use when NHI rates are low and travel time to the nearest clinic is under 30 minutes. It is very important for health professionals to ensure convenient and friendly accessibility to medical resources for families of young children.

Administering the correct medication and adopting proper storage methods are important issues in medication safety. Although multilingual explanations may be beneficial to immigrant parents' perceptions of medication content, medication administration habits, such as administering suppositories to febrile children, storing medications in the refrigerator, mixing Chinese medicines with medication, and administering previously prescribed drugs or giving other children's medication to a sick child, are more significant to young children's health. Medical professionals, including pharmacists and public health nurses, may offer additional services for immigrant mothers. This study has also identified the need for further educational programs on medication administration for immigrant mothers, especially regarding medication misuses and misunderstandings. In addition, making medical resources easily accessible is a key element. Many countries may not have inexpensive NHI rates or a high density of clinics, as in Taiwan, but they may explore possible solutions to increase the accessibility of medical resources for immigrant families. 


\section{Acknowledgements}

National Immigration Agency, Taiwan, Project No. 1001F304.

\section{References}

Bates, D. W. (1996). Medication errors. How common are they and what can be done to prevent them? Drug Safety, 15(5), 303-310. http://dx.doi.org/10.2165/00002018-199615050-00001

Chang, M. C., Chen, Y. C., Chang, S. C., \& Smith, G. D. (2011). Knowledge of using acetaminophen syrup and comprehension of written medication instruction among caregivers with febrile children. Journal of Clinical Nursing, 21, 42-51. http://dx.doi.org/10.1111/j.1365-2702.2010.03668.x

Department of Health and Welfare. (2013). Table 5.1 Numbers of clinics and hospitals, medical professions, and hospital beds (1954-2012) in Taiwan. Retrieved from http://win.dgbas.gov.tw/dgbas03/ca/yearbook/ index $5 . \mathrm{htm}$

DeWalt, D. A., Drilling, M. H., Rosenthal, M. S., \& Pignone, M. P. (2007). Low parental literacy is associated with worse asthma care measures in children. Ambulatory Pediatrics, 7(1), 25-31. http://dx.doi.org/10. 1016/j.ambp.2006.10.001

Håkonsen, H., \& Toverud, E. (2012). Cultural influences on medicine use among first-generation Pakistani immigrants in Norway. European Journal of Clinical Pharmacology, 68, 171-178. http://dx.doi.org/10. 1007/s00228-011-1111-7

Hughes, R. G., \& Edgerton, E. A. (2005). Reducing Pediatric Medication Errors: Children are especially at risk for medication errors. American Journal of Nursing, 105(5), 79-84. http://dx.doi.org/10.1097/00000446-200 505000-00035

Kao, H. S., \& Lynn, M. R. (2009). Use of the measurement of medication administration hassles with Mexican American family caregivers. Journal of Clinical Nursing, 18, 2596-2603. http://dx.doi.org/10.1111/j.1365 $-2702.2008 .02752 . \mathrm{x}$

Lo, S., Sharif, I., \& Ozuah, P. O. (2006). Health literacy among English-speaking parents in a poor urban setting. Journal of Health Care for the Poor and Underserved, 17, 504-511. http://dx.doi.org/10.1353/hpu.2006. 0109

Marks, J. R., Schectman, J. M., Groninger, H., \& Plews-Ogan, M. L. (2010). The association of health literacy and socio-demographic factors with medication knowledge. Patient Education and Counseling, 78, 276-372. http://dx.doi.org/10.1016/j.pec.2009.06.017

Ministry of Education. (2015). Number of Children from Transnational Marriage Families (2012/2013 academic year). Retrieved from http://www.edu.tw/pages/detail.aspx?Node=4075\&Page=20046\&Index=5\&WID= 31d75a44-efff-4c44-a075-15a9eb7aecdf

National Health Administration. (2014). National health service. Retrieved from http://www.nhi.gov.tw/ webdata/webdata.aspx? $m e n u=18 \&$ menu_id $=683 \&$ webdata_id $=384$

National Immigration Agency. (2013). Numbers of foreign spouses from Southeast Asia and PR China. Retrieved from http://www.immigration.gov.tw/ct.asp?xItem=1247109\&ctNode=29699\&mp=1

OECD Health Statistics. (2013). Physicians density per 1000 population (head counts). Retrieved from http://stats.oecd.org/Index.aspx?DataSetCode=HEALTH_REAC

OECD. (2013). International migration outlook 2013 (Table A.1. Inflows of foreign population into OECD countries and the Russian Federation). Retrieved from http://www.oecd.org/berlin/publikationen/ migration-outlook.htm

Phillips, J., Beam, S., Brinker, A., Holquist, C., Honig, P., Lee, L. Y., \& Pamer, C. (2001). Retrospective analysis of mortalities associated with medication errors. American Journal of Health-System Pharmacy, 58(19), 1835-1841.

Suurmond, J., Uiters, E., de Bruijne, M. C., Stronks, K., \& Essink-Bot, M. (2011). Negative health care experiences of immigrant patients: A qualitative study. BMC Health Services Research, 11, 10. http://dx.doi.org/10.1186/1472-6963-11-10

Väänänen, M. H., Lyles, A., \& Airaksinen, M. (2008). Finnish immigrants’ experience of community pharmacy services in Spain: An example of a developing E.U. issue. International Journal of Health Service, 38(2), 293-312. http://dx.doi.org/10.2190/HS.38.2.e 
Watt, L., Gulati, S., Shaw, N. T., Sung, L., Dix, D., Poureslami, I., \& Klassen, A. F. (2012). Perceptions about complementary and alternative medicine use among Chinese immigrant parents of children with cancer. Supportive Care in Cancer, 20(2), 253-260. http://dx.doi.org/10.1007/s00520-010-1063-y

Wilson, E., Chen, A. H., Grumbach, K., Wang, F., \& Fernandez, A. (2005). Effects of limited English proficiency and physician language on health care comprehension. Journal of General Internal Medicine, 20, 800-806. http://dx.doi.org/10.1111/j.1525-1497.2005.0174.x

Yeh, Y. C., \& Huang, W. T. (2012). Medication Safety Knowledge of Immigrant Mothers in Taiwan and Administration Misuse with Their Children. Paper presented at the East Asian Social Policy Research Network Annual Conference, 16th-18th July, York: University of York.

Yin, H. S., Dreyer, B. P., van Schaick, L., Foltin, G. L., Dinglas, C., \& Mendelsohn, A. L. (2008). Randomized controlled trial of a pictogram-based intervention to reduce liquid medication dosing errors and improve adherence among caregivers of young children. Archives of Pediatrics and Adolescent Medicine, 162, 814-822. http://dx.doi.org/10.1001/archpedi.162.9.814

Yin, H. S., Mendelsohn, A. L., Wolf, M. S., Parker, R. M., Fierman, A., van Schaick, L., ..., Dreyer, B. P. (2010). Parents' medication administration errors: Role of dosing instruments and health literacy. Archives of Pediatrics and Adolescent Medicine, 164, 181-186. http://dx.doi.org/10.1001/archpediatrics.2009.269

\section{Copyrights}

Copyright for this article is retained by the author(s), with first publication rights granted to the journal.

This is an open-access article distributed under the terms and conditions of the Creative Commons Attribution license (http://creativecommons.org/licenses/by/3.0/). 